\title{
Nature: A Recurrent Theme in Wordsworth's Poetry
}

Lok Raj Sharma*

Associate Professor of English, Makawanpur Multiple Campus, Hetauda, Nepal

DOI: 10.36348/sijll.2021.v04i01.003

| Received: 13.12.2020 | Accepted: 29.12.2020 | Published: 13.01.2021

*Corresponding author: Lok Raj Sharma

\section{Abstract}

This article attempts to deal with nature as a recurrent theme in William Wordsworth's poetry. He is one of the greatest romantic English poets. He views nature as a living entity that is a source of pleasure and education for him. He has given us sufficient heart-touching and beautiful poems that are the enduring treasures of romanticism, but only a few popular poems that reveal the growth and development of his love for nature, his concept of nature mysticism, joy in nature, universal love in nature, spiritual unity of nature, bond between nature and man, soothing influence and healing power of nature and nature's teaching potentiality have been taken from the corpus of his vast works under consideration for the study. Most of his poems can be well understood and analyzed through a vigilant consideration regarding his treatment of nature.

Keywords: Nature, Poetry, Theme, William Wordsworth.

Copyright () 2021 The Author(s): This is an open-access article distributed under the terms of the Creative Commons Attribution 4.0 International License (CC BY-NC 4.0) which permits unrestricted use, distribution, and reproduction in any medium for non-commercial use provided the original author and source are credited.

\section{INTRODUCTION}

William Wordsworth (7 April 1770 - 23 April 1850) was a great Romantic English poet. He was born in Cockermouth, Cumberland, located in the Lake District of England. He was the second child of his father John Wordsworth, who was a legal representative of James Lowther, 1st Earl of Lonsdale, and his mother Anne, who was the only daughter of William Cookson, mercer of Penrith. Wordsworth was Britain's poet laureate from 1843 to 1850 . Wordsworth is best known for "Lyrical Ballads" (1798) that was written in collaboration with Samuel Taylor Coleridge. "The Prelude" (1799) that is a Romantic epic and semiautographical poem is considered his magnum opus. Besides these, he has enriched English literature with his large number of poems like "Ode on Intimations of Immortality" (1807), "The Solitary Reaper" (1807), "Composed upon Westminster Bridge" (1807), "The World is Too Much with Us" (1807), "French Revolution" (1807), "Nuns Fret Not" (1807), "The Daffodils" (1807), "To the Cuckoo" (1802), "Lucy Gray' (1800), "Revolution and Independence' (1807), 'To Milton" (1802) and so on.

"Lyrical Ballads" is regarded the Manifesto of the Romantic Movement in poetry. William Wordsworth, Percy Bysshe Shelley, Samuel Taylor Coleridge, Lord Byron John Keats, Walt Scott, William Blake etc. are popular romantic poets of English literature.
Romantic poetry is a type of poetry that is marked with the characteristics of subjectivity, spontaneity, depiction of nature, supernaturalism, simple poetic diction, revolt, melancholy and veneration of rustic life. The prime objective of this article is to deal with the divergent dominant roles of nature depicted in Wordsworth's poetry.

\section{LITERATURE REVIEW}

Nature is a broad term. It refers to the physical or material world along with its phenomena such as snowing, raining, winding, clouding, fogging, blowing, flowing, thundering, lightening etc. It refers to all the living and non-living beings such as animals, birds, plants, flowers, fish, insects, rocks, rivers, mountains, clouds, snow, soil, ponds, hills etc. The occurrence of such natural things and natural phenomena influences not only the poets, but also influences ordinary people in shaping their ideologies and life styles. Poets are specially influenced by nature. Oxford Dictionary of English (2003) describes nature as "the phenomena of the physical world collectively, including plants, animals, the landscape, and other features and products of the earth as opposed to humans or human creations" (p.1172) [1]. This definition indicates that all the things and events that are not created by humans belong to nature.

Poetry is flexible because of its open endedness. It can be interpreted and analyzed from 
diverse perspectives. Similarly, readers can perceive different themes in a single poem. A theme is a crux of an expression in writing or speech. Cuddon [2] asserts that "the theme of a work is not its subject, but rather its central idea, which may be stated directly or indirectly" (p.913). Harmon [3] views the theme as "the abstract concept that is made concrete through representation in person, action, and image" (p.521). Kirszner and Mandell [4] give a descriptive definition of the theme and maintain that the theme of a work of literature is its central or dominant idea. It is "conveyed through the selection and arrangement of details; through the emphasis of certain words, events, or images; and through the actions and reactions of characters" (p.3). Nature is one of the vital characters and themes in Wordsworth's poetry.

Poetry is a popular form of literature. It is more musical, more emotional, more obscure, more implied and more figurative than other genres of literature. Wordsworth [5] defines poetry as "the spontaneous overflow of powerful feeling; it takes its origin from emotion recollected in tranquility" (p.213). His definition emphasizes the spontaneity of feelings, and recollection of events in peaceful mood for poetic creation. Johnson [6] views poetry as "the art of uniting pleasure with truth by recalling imagination to the help of reason" (p.57). He evaluates poetry as an art that unites pleasure and truth. Smith (1968) asserts that imagination is "the power that leads us to truth; it is at once vision and reconstruction" (p.16). For Hudson [7], poetry is "an interpretation of life through imagination and feelings" (p.80). He associates poetry with description of life. The description is intensified through imagination and feelings that are the backbone of poetry. Malik [8] maintains that "the human heart, feelings and emotions constitutes the essence of poetry" (p.87).

\section{Views on Wordsworth and his treatment of Nature}

Several critics and writers have expressed their views about Wordsworth and treatment of nature in his poetry. Parab [9] remarks that "Wordsworth as romantics urges that a union with nature is what frees the mind from the stir and thrust of its own dark emotions" (p.1589). Mir [10] asserts that "his heart is enriched in the company of nature and he does not want to leave its company" (p. 723). Zeng [11] affirms that "he eulogizes nature's landscape---pastoral countryside full of flowers, trees, birds, sky and streams, he pays attention to the influence of nature on human's hearts" (p.30). For Jabeen [12], "nature is beautiful, enjoyable and a source of pleasure for Wordsworth" (p.194). Khan [13] admires Wordsworth and writes "he can foresee the future pleasures, or rather the unification with nature; the thoughts of nature produce a heightened sense of mental stimulation in the poet" (p.2). Wordsworth points out the beauty of the nature and its harmony. Bilal and Cheema [14] claim that "this harmony of the nature reminds him the disharmony of the world" (p.32). Yang and Zeng [15] think that "he regarded nature as his spiritual home" (p.338). Neha [16] maintains that "Wordsworth emphasized the moral influence of Nature. He spiritualized nature and regarded her as a great moral teacher, as the best mother, guardian and nurse of man, and as an elevating influence" (p.1). Huang, Pei and Fu [17] assert that living in the crowded and noisy society, Wordsworth felt greatly miserable. Only in nature, "he can find beauty and purity going into his own thinking; natural world is his ideal word" (p.114). Almiqdady, AbuMelhim and Al-Sobh [18] consider William Wordsworth as "a worshipper of nature, nature's devotee or high-priest, and his love of nature was probably truer and tenderer than that of any other English poet" (p.156).

Compton-Rickett [19] mentions that it was Wordsworth's aim as a poet to "seek for beauty in meadow, woodland, and the mountain top, and to interpret this beauty in spiritual terms" (p.308). Rader [20] believes that "the poet recognizes a sense of joy in nature and a blessed power that rolls through all things about us" (p.188). Willy [21] talking about Wordsworth points out that "nature's healing power, which for some may be merely an outworn doctrine, was for him a fact of experience, and the rapture of that experience" (p.283). Read [22] concerning the theme of Wordsworth's poetry maintains that nature as "the highest theme of poetry" (p.127). Symons [23] informs that Wordsworth conveys the live part of natural truth to us as "no other poets have ever done, no other poets having had in him so much of the reflective peasant" (p.92). Wordsworth is close to the common places of life. Smith [24] contends that "Wordsworth had never any wish to escape from the common places of life; he accepted them all, and viewed them with a calmness and a courage that could never been shaken" (p.13). Nature is superior to humans. Compton-Rickett [19] asserts that "apart from the sanctifying touch of nature, men and women are poor creatures to Wordsworth; the farther we travel from Nature, the more paltry we become" (p.311).

Grierson and Smith [25] consider that " Wordsworth had keen ear too for all natural sounds, the calls of beasts and birds, and the sounds of winds and waters; the soughing of boughs in a high wind set his mind working, and he composed thousands of lines wandering by the side of a stream" (p.307). Wordsworth takes nature as a teacher. Legouis and Cazamian [26] claim that "to him nature appears as a formative influence superior to any other, the educator of senses and mind alike" (p.1010). Arnold [27] admires Wordsworth and asserts that "his poetry is great because of the extraordinary power with which he feels the joy offered to us in nature" (p.153). Besides a great lover of nature, Wordsworth was a moralist. The same belief is expressed by Compton-Rickett [19] that "he is a moralist at heart" (p.311). Mukherjee [28] 
considers Wordsworth "a prolific writer" (p.9). His contribution of romantic poetry to the field of English literature is paramount.

\section{Representation of Nature in Wordsworth's poetry}

The poet presents Nature in divergent ways in his poetry. He views Nature as a source of love, perpetual joy, soothing and healing power, knowledge and spirituality. Nature and God become one for him. He believes that Nature is the Universal Spirit guiding anyone who like to be guided by her.

The poet in his boyish days looked upon Nature as a source and scene for animal pleasure like skating, riding, fishing and walking. His first love was his romantic passion for Nature as he describes in "Tintern Abbey":

The coarser pleasure of my boyish days,

And their glad animal movements (Lines: 73-74)

In "The Prelude Book VIII", the poet in this early stage portrays Nature as:

But secondary to my own pursuits

And animal activities, and all

Their trivial pleasures (Lines: 344-346)

In the second stage, he develops a passion for sensuous beauty of Nature. He views Nature with a purely physical passion and he finds himself in close communion with Nature, as he mentions in "The Prelude Book II":

The mind lay open to a more exact

And close communion. (Lines: 302-303)

He goes on describing how during this period Nature becomes the object of a passion. "In Tintern Abbey", he writes:

I cannot paint,

What then I was. The sounding cataract

Haunted me like a passion: the tall rock,

The mountain, and the deep and gloomy wood,

Their colors and their forms (Lines: 77-81)

As the poet sees the French Revolution and human sufferings, they make him realize the dignity of the common folk. Then his love of Nature becomes linked with the love of man. He can hear the music of humanity in Nature, as he asserts in "Tintern Abbey":

The still sad music of humanity,

Nor harsh nor grating, though of ample power

To chasten and subdue. (Lines: 93-95)

He composes "Ode on Intimations of Immortality" in this stage to reflect human-heartedness. He affirms:

The Clouds that gather round the setting sun

Do take a sober coloring from an eye

That hath kept watch o'er man's mortality;

Another race hath been, and other palms are won.

(Lines: 196-199)
In the final stage of his writings, he makes the spiritual interpretation of Nature. He perceives God in Nature and Nature in God. It is known as the stage of Pantheism. This faith is expressed in the poem "Tintern Abbey":

A motion and a spirit, that impels

All thinking things, all objects of all thought,

And rolls through all things. (Lines: 102-104)

The poet observes that the waves in the lake are dancing, but the daffodils excell the dancing waves in their merriment. He feels happy in such a delightful company. These lines of the poem "Daffodils" present Nature as a source of perpetual joy.

The waves beside them danced; but they

Out-did the sparkling waves in glee:

A poet could not but be gay,

In such a jocund company: (Lines: 13-16)

The poet mentions that whenever he is in a thoughtful mood, the daffodils flash upon his inward eye and bestow his heart with pleasure. He expresses: And then my heart with pleasure fills,

And dances with the daffodils. (Lines: 23-24)

The poet is highly influenced by seeing the beautiful flower daisy. The flower seems cheerful and fresh in the morning ray. He describes the flower as "alert and gay". His spirits play with familial happiness that he mentions in the poem "To the Daisy" as:

Fresh smitten by the morning ray,

When thou art up, alert and gay,

Then, cheerful Flower! my spirits play

With kindred gladness: (Lines: 57-60)

The poet considers Nature being an eternal source of joy. Although Lucy is no longer alive in earthly terms, the poet believes that she will still experience "vital feelings of delight" as she grows up into her "stately height" and into maturity. Wherever she is, wherever Nature has taken her, she will continue to grow up there, with all feelings of life and vitality. He resolves to give these thoughts to Lucy daily, so that even though she exists in a different realm from his reality, they will together live here in this happy valley. He expresses this belief in the poem "Three Years She Grew in Sun and Shower" as:

And vital feelings of delight

Shall rear her form to stately height,

Her virgin bosom swell;

Such thoughts to Lucy I will give

While she and I together live

Here in this happy dell. (Lines: 31-36)

The poet reveals his belief in the "To My Sister" that he recognized a sense of joy in Nature with the blessing power. He looks around and takes in all the "blessings in the air." The world seemed affluent to him. It is filled with a "sense of joy" that yields itself to 
the "bare trees" and mountains, as well as the "green field." He describes:

There is a blessing in the air,

Which seems a sense of joy to yield

To the bare trees, and mountains bare,

And grass in the green field. (Lines: 5-8)

The poet expresses his belief that every flower rejoiced the air it breathed. He writes in the "Lines Written in Early Spring" as:

And 'tis my faith that every flower

Enjoys the air it breathes. (Lines 11-12)

In the "Lines Written in Early Spring", he perceives that even the birds and the budding twigs are enjoying the air in the lap of Nature.

And I must think, do all I can,

That there was pleasure there. (Lines: 19-20)

The poet feels great joy when he sees a rainbow in the sky. He used to enjoy a lot when he saw it in the sky in his childhood. In his short poem "My Heart Leaps up When I Behold", he states:

My heart leaps up when I behold

A rainbow in the sky: (Lines: 1-2)

The poet realizes that love comes from the earth to humankind and goes back to the earth again. It is a persistent cycle that everyone should accept and behave in the best they can. This association of love is emphasized through the repetition of the prepositional phrase "from...." as in the poem "To My Sister":

Love, now a universal birth,

From heart to heart is stealing,

From earth to man, from man to earth:

It is the hour of feeling. (Lines: 21-24)

Wordsworth makes wonderful descriptions of divergent aspects of Nature in his poetry. He has given delicate and subtle expression to the sensuous glee of the world of Nature. He feels the joy of spring in the poem "It was April Morning: Fresh and clear". He expresses:

It was an April morning: fresh and clear

The Rivulet, delighting in its strength,

Ran with a young man's speed; and yet the voice

Of waters which the winter had supplied

Was softened down into a vernal tone. (Lines: 1-5)

He describes Nature in his Prelude Book II beautifully:

The calm

And dead still water lay upon my mind

Even with a weight of pleasure, and the sky

Never before so beautiful, sank down

Into my heart, and held me like a dream (Lines: 177181)

He describes all the little graces and charms of a summer day vividly in the poem "The Ruined Cottage". He describes:
$\mathrm{T}$ was summer and the sun was mounted high.

Along the south the uplands feebly glared

Through a pale steam, and all the northern downs

In clearer air ascending shewed far off

Their surfaces with shadows dappled o'er

Of deep embattled clouds (Lines: 1-6)

In the "Poetical Works" (1849-1850), he reflects the spirit of June into a couplet as given below:

Flaunting Summer when he throws

His soul into the briar rose. (Lines: 85-86)

Wordsworth is not only a keen observer, but he is also a sharp hearer of Nature. In the poem "The Solitary Reaper", he mentions the voice of a singing girl in the field:

A voice so thrilling ne'er was heard

In spring-time from the Cuckoo-bird,

Breaking the silence of the seas

Among the farthest Hebrides. (Lines: 13-16)

Wordsworth views Nature as a living entity. The indwelling spirit in Nature imparts its own consciousness to all objects. The poet describes the sea, the moon, the winds and flowers using personification in the poem "The World is Too Much with Us":

This Sea that bares her bosom to the moon; The winds that will be howling at all hours, And are up-gathered now like sleeping flowers; (Lines: 5-7)

He claims that he sees the things feel as he writes in the poem "The Prelude Book III":

To every natural form, rock, fruit, and flower, Even the loose stones that cover the highway I gave a moral life: I saw them feel. (Lines: 98-100)

His believes that all the objects of Nature are sentient beings. His faith is clearly expressed in "Lines Written in Early Spring":

And this is my faith that every flower

Enjoys the air it breathes. (Lines: 11-12)

His belief in the inner life of Nature is also maintained in "The Prelude Book I". Once he steals a bird from the trap of a boy, he hears a voice among the solitary hills:

I heard among the solitary hills

Low breathings coming after me, and sounds

Of undistinguishable motion, steps

Almost as silent as the turf they trod. (Lines: 59-62)

He realizes a grim shape walking after him when he steals a boat to explore the silent lake in the evening. He feels as if a huge peak uprears its head as he expresses in "The Extract from the Prelude":

And growing still in stature the grim shape

Towered up between me and the stars, and still, For so it seemed, with the purpose of its own And measured motion like a living thing, 
Strode after me. (Lines: 25-29)

The poet believes that Nature has a soothing as well as healing power with which She can soothe and heal the suffering folks. The poet asserts that Nature as Mother would nurture Lucy very well. Lucy will be playful and merry like a young deer with that wild and tame less joy. She will be full of energy to go high up as the water spring on top of the mountain; a source of a river. She will possess that gentle breeze that would act as a soothing and healing balm for her wounds. She will also learn to be silent and calm with the silent inanimate objects of Nature. In "Three Years She Grew Up in Sun and Shower', the poet maintains:

She shall be sportive as the fawn

That wild with glee across the lawn

Or up the mountain springs;

And hers shall be the breathing balm,

And hers the silence and the calm

Of mute insensate things. (Lines: 13-18)

Martha Ray Kills her baby because she is betrayed by her lover. She goes to the place all the time, both in the day and at night and in all kinds of weather. She always recalls her infant with a sense of agony, regret and suffering: Nature, the true shelter of Martha, hopefully sympathizes passionately with her love and suffering. In "The Thorn”, he expresses:

And she is known to every star

And every wind that blows, (Lines: 69-70)

The poet mentions that even a cruel person and a sinner go to Nature for solace. In the poem "Peter Bell", he describes Peter Bell as a hard-hearted sinner. He goes to Nature and spends time. He is unknowingly affected by the softening influence of nature.

At noon, when by the forest's edge

He lay beneath the branches high (Lines: 261-262)

The poet establishes the relationship between human experiences and the natural landscape. He perceives Nature as stimulus, anodyne and soothing. In the poem "The Ruined Cottage", he states:

I well remember that those very plumes,

Those weeds, and the high spear-grass on that wall,

By mist and silent rain-drops silver'd o'er,

As once I passed did to my heart convey,

So still an image of tranquility,

So calm and still, and looked so beautiful (Lines: 327332)

In "Tintern Abbey", he recounts how Nature influenced him, brought him peace and tranquility of mind even when he was in the din and bustle of the city. He contends:

These beauteous forms,

Through a long absence, have not been to me

As is a landscape to a blind man's eye:

But oft, in lonely rooms, and 'mid the din

Of towns and cities, I have owed to them,
In hours of weariness, sensations sweet,

Felt in the blood, and felt along the heart;

And passing even into my purer mind

With tranquil restoration: (Lines 23-31)

Wordsworth views Nature as a universal teacher. He replies his friend Matthew that the bookish knowledge does not satisfy him. It can't satisfy his will. A person sees, hears, and feels what is around him, whether he wants to or not, But Nature speaks to him in the way he likes. The poet in "Expostulation and Reply" says:

The eye--it cannot choose but see;

We cannot bid the ear be still;

Our bodies feel, where'er they be,

Against or with our will. (Lines: 17-20)

He further asserts a person's intuition; his Godgiven inner voice speaks to him, feeding his mind as Nature does. Thus, a man can learn in the thoughtful mood. He maintains:

Nor less I deem that there are Powers

Which of themselves our minds impress;

That we can feed this mind of ours

In a wise passiveness. (Lines: 21-24)

The poet tells his friend Matthew that books are dull and tedious. Rather than reading, he should venture outside to where the linnet and the throstle are singing beautiful songs containing more wisdom than any book. Nature has more to teach than books, and that he should go outside rather than seek refuge in dry pages. He suggests this in "The Tables Turned" by stating:

Come forth into the light of things,

Let Nature be your teacher. (Lines: 15-16)

The poet asks his friend to leave his books and go out into the open area. He can learn more about man, goodness and evilness from the spring green forests than from all the wise people. He mentions this notion in "The tables Turned" as:

One impulse from a vernal wood

May teach you more of man,

Of moral evil and of good,

Than all the sages can. (Lines: 21-24)

The poet suggests that even though Nature brings humanity sweet traditions of intelligence, we tend to ruin that knowledge by dissecting it. We should come to Nature ready to learn with a heart that watches and receives. In "The table Turned", he claims:

Sweet is the lore which nature brings;

Our meddling intellect

Mis-shapes the beauteous forms of things;

We murder to dissect. (Lines: 25-28)

Wordsworth believes that there is a bond between Nature and man. Humans grow and behave into the mist of the interplaying forces of Nature. The 
poet in "Three Years She Grew in Sun and Shower", he quotes Nature's Voice for Lucy:

Three years she grew in sun and shower,

Then Nature said, "A lovelier flower

On earth was never sown;

This Child I to myself will take;

She shall be mine, and I will make

A Lady of my own. (Lines: 1-6)

The poet addresses a sweet highland girl and tells her that a very shower of beauty is her earthly dower. He depicts her association with Nature in "To a Highland Girl". He describes:

And these grey rocks; that household lawn;

Those trees, a veil just half withdrawn;

This fall of water that doth make

A murmur near the silent lake;

This little bay; a quiet road

That holds in shelter thy Abode (Lines: 5-10)

The poet exposes the bond between the rebellious Toussant L'Ouverture and Nature in terms of his power with other powers in Nature in the poem “Toussant L'Ouverture" by asserting:

Thou hast left behind

Powers that will work for thee; air, earth, and skies;

There is not a breathing of the common wind

That will forget thee; thou hast great allies. (Lines: 912)

The poet believes that there is pre-existing harmony between the human mind and Nature. The poet in his poem "The Recluse" points out:

For the discerning intellect of Man

When wedded to this goodly universe

In love and holy passion, shall find these:

Paradise, and groves Elysian, and Fortunate Fields. (Lines: 39-42)

The poet desires every day to be tied together by an ongoing love for Nature in the poem "My heart leaps up when I behold". The phrase "natural piety" implies that he considered his feeling for Nature to be so reverent that seeing a rainbow was an almost spiritual experience. It indicates his spiritual unity with Nature.

And I could wish my days to be

Bound each to each by natural piety. (Lines: 8-9)

Wordsworth depicts spiritual unity of Nature in his poetry. The spiritual unity of Nature spreads in the universe. He declares in "The Excursion" as:

Whate'er exists hath properties that spread

Beyond itself, communicating good,

A simple blessing, or with evil mixed;

Spirit that knows no insulted spot (Lines: 87-90)

The spiritual unity of Nature can also be noticed in "Ode on Intimation of Immortality". He asserts:

The winds come to me from the field of sleep,
And all the earth is gay. (Lines: 28-29)

The poet hears the voice of Nature in different forms in "Lines Composed at Grasmere". He contends:

Loud is the vale! the voice is up

With which she speaks when storms are gone,

A mighty unison of streams!

Of all her Voices, One! (Lines: 1-4)

All the extracts mentioned above obviously indicate Wordsworth's literary competence in handling Nature precisely and genuinely in his English poetry that deals with Nature as a recurrent theme.

\section{CONCLUSION}

Wordsworth is one of the most influential romantic poets of English of the nineteenth century. His poems depict his strong love and passion for Nature. He presents her as a perpetual source of joy and teaching. He views her as a universal teacher. He believes that she retains soothing and healing power. Moreover, she has power to kindle and restrain the humans. The poet perceives her as a living entity and sees a close bond between her the humans. Nature exists as a recurrent theme in his poetry. Most of his poems can be well understood and enjoyed when we keep on discerning his treatment of Nature.

\section{REFERENCES}

1. Soanes, C., \& Stevenson, A. (Eds). (2003). Oxford dictionary of English ( $2^{\text {nd }}$ ed.) New Delhi: Oxford University Press.

2. Cuddon, J. A. (1999). Literary terms and theory. London: Penguin Book.

3. Harmon, W. (2009). A handbook to literature. New Delhi: Dorling Kindersley.

4. Kirszner, L. (1991). Literature: Reading, reacting, Writing. Boston: Heinie \& Heinie.

5. Wordsworth, W., \& Coleridge, S. T. (1989). Preface to the lyrical ballads. Lahore: Kitab Mahal.

6. Johnson, S. (1965). Life of Milton. London: Macmillan and Co. Ltd.

7. Hudson, W. (2002). An introduction to the study of English literature. New Delhi: Robin Books.

8. Malik, G. R. (1988). .Iqbal and the English romantics. New Delhi: Atlantic Publishers.

9. Parab, V. V. (2015). The romantic philosophy in the poetry of William Wordsworth and Samuel Taylor Coleridge. The International Journal of Social Sciences and Humanities Invention, 2 (9), 1572-1591.

10. Mir, I. M. (2016). Treatment of nature by Muhammad Iqbal and William Wordsworth. International Journal of English Language, Literature and Translation Studies, 3 (3), 722-726.

11. Zeng, X. (2018). On the natural aesthetics of Wordsworth's poetry. Advances in Social Science, Education and Humanities Research, 196, 30-32. 
12. Jabeen, R. (2018). Nature: In the hands of Wordsworth. International Journal of Linguistics, Literature and Translation, 1 (2), 194-203.

13. Khan. F. S. (2013). Emotions recollected in tranquility: Wordsworth's concept of poetic creation. International Journal of Humanities and Social Science, 3(3):1-5.

14. Bilal, H. A., \& Cheema, A. (2012). Stylistic analysis of Wordsworth's poem early spring. British Journal of Humanities and Social Sciences, 5(2):25-34.

15. Yang, H., \& Zeng, R. (2018). Spiritual consolation from nature -- Exploration of poetry creation principles of daffodils. International Conference on Arts, Linguistics, Literature and Humanities (ICALLH 2018). Francis Academic Press, UK.337-340.

16. Neha. (2014). A study on William Wordsworth as a nature poet. Journal of Advances and Scholarly Researches in Allied Education, 7(13),1-4

17. Huang, X., Pei, F., \& Fu, C. (2014). On lyrical poetry of Wordsworth, a poet of nature. Advances in Literary Study, 2, 113-115.

18. Almiqdady, M. Z. Abu-Melhim, A. H., \& AlSobh, M. A. (2015). The Concept of nature in the poetry of William Wordsworth and Robert Frost:
A comparative study. Arab World English Journal, 3, 153-166.

19. Compton-Rickett, A. (1963). A history of English literature. London: Thomas Nelson \& Sons Ltd.

20. Rader, M. (1967). Wordsworth: A philosophical approach. London: Oxford University Press.

21. Willy, B. (1950). The eighteen century background. London: Chatto \& Windus.

22. Read, H. (1949). Wordsworth. London: Faber \& Faber Ltd.

23. Symons, A. (1969). The romantic movement in English poetry. New York: Phaetonee.

24. Smith, D. N. (1965). Introduction to Wordsworth: Poetry and prose. London: Oxford University Press.

25. Grierson, H., \& Smith, J. C. (1966). A critical history of English poetry. London: Penguin Books Ltd.

26. Legouis, E., \& Cazamian, L. (1957). A history of English literature. London: J.M. Dents \& Sons Ltd.

27. Arnold, M. (1915). Essays in criticism -second series. London: Macmillan \& Co. Ltd.

28. Mukherjee, S. K. (1996). William Wordsworth: An evaluation of his poetry (6th ed.). New Delhi: Rama Brothers. 